\title{
Physicochemical Characterization and Phenolic Profile of Oiti Fruits (Licania tomentosa Benth Fristch)
}

\author{
Luciane de Lira Teixeira, ${ }^{1,2}$ Gabriel Araujo Silva, ${ }^{2}$ José Benilson Martins Macedo, ${ }^{2}$ Maria das Graças \\ Almeida $^{2}$ and Maria de Fátima Vitória de Moura' \\ 'Institute of Chemistry, Federal University of Rio Grande do Norte (UFRN), Salgado Filho Avenue, s/n, Natal, Rio Grande do Norte, 59078-979, Brazil. \\ ${ }^{2}$ Department of Clinical and Toxicological Analysis, Federal University of Rio Grande do Norte (UFRN), General Cordeiro de Faria Avenue, s/n, Natal, Rio \\ Grande do Norte, 59012-570, Brazil
}

*Correspondence: Dr. Luciane de Lira Teixeira,Address: - Department of Clinical and Toxicological Analysis, Federal University of Rio Grande do Norte (UFRN), General Cordeiro de Faria Avenue, s/n, Natal-RN, 590 I 2-570, Brazil. Tel +55 84 99|72-9905,

Email lucianeliratfarmaciaufrn@gmail.com

Received: December 06, 2018 | Published: January 18, 2019

Copyright@ 2019 Teixeira et al. This is an open access article distributed under the terms of the Creative Commons Attribution License, which permits unrestricted use, distribution, and reproduction in any medium, provided the original author and source are credited.

\begin{abstract}
Oiti (Licania tomentosa Benth Friscth) belongs to the Chrysobalanaceae family; it's native to the Brazilian tropical forest (Caatinga). Although existing studies have demonstrated the antioxidant, anticholinesterase and antibacterial effects of its leaf extracts, a lack of knowledge about oiti fruits persist. The present study aimed to analyse Oiti fruits. Oiti fruits collected from Natal city, Rio Grande do Norte, Brazil. They were separated into peel, pulp and seed. Macronutrients and minerals were analysed. Minerals were studied by optical emission spectrometry with inductively coupled argon plasma. Peel and pulp hydroethanolic extracts were evaluated for total phenolic content, total flavonoid content, antioxidant capacity and reducing power. Additionally, the phenolic profile of peel and pulp extracts were analysed by high-performance liquid chromatography. As results, Oiti fruits showed around $36.14 \pm 7.86 \mathrm{~g}$ of weight with $65.82 \%$ of pulp, 21.8 , 5.67 and $18.4 \%$ of fibre in the peel, pulp and seed, respectively, $0.79,0.26$ and $2.04 \%$ of protein in the peel, pulp and seed, respectively, and $3.73,0.40$ and $0.05 \%$ lipids in the peel, pulp and seed, respectively. The analysed pulp also contained $20.70 \mathrm{mg}$ total sugar per $100 \mathrm{~g}$ fruit. Furthermore, phytochemical analysis indicated that the total phenolic content in peel and pulp were not correlated to their antioxidant capacity, but that pulp extracts exhibit a moderate correlation with reducing power. Gallic acid, catechin, rutin and kaempferol were quantified in fruit peel, gallic acid and kaempferol in pulp, being the flavonols main flavonoids in Oiti fruits. Oiti fruits have potential for use in the food industry and their biological properties must be explored further to provide stimulus to its consumption.
\end{abstract}

Keywords: nutrients, minerals, flavonols, oiti fruit

\section{Introduction}

The study of plants and their fruits with medicinal proprieties is important for the development of new therapeutic strategies, as well as to promote the preservation and sustainable use of native plants ${ }^{1}$. Several exotic Brazilian fruits such as camu-camu, ${ }^{2,3}$ açaí, ${ }^{4}$ juçara, ${ }^{5}$ grumixama,${ }^{6}$ uvaia $^{7}$ and guajuru ${ }^{8}$ have been proven to contain compounds with relevant biological activities, such as antioxidant, anti-inflammatory, antiproliferative and anti-diabetes activity, among others, demonstrating the importance of studying exotic fruits.

Licania tomentosa Benth belongs to the Chrysobalanaceae family, an order and superorder of Rosiflorae Rosales, and is also known as Oiti. Licania species are known as oiti, and the oil extracted from their seeds is used as a substitute for ink drying oil. ${ }^{9}$ Furthermore, oiti is a native plant of Caatiga, a type of Brazilian tropical forest. The Chrysobalanaceae family is composed of 20 genera and about 500 species of shrubs and trees, with habitats distributed throughout tropical and subtropical regions. ${ }^{10,11}$ Licania tomentosa Benth is widely used in Brazilian garden squares to provide shadow. ${ }^{12}$ In addition, its fruits are drupaceous, ellipticals, monospermics, succulents and indehiscents with smooth and glabrous exocarp of yellow to orange colouration, yellow and fibrous mesocarp, and membranaceous endocarp ${ }^{13}$ The harvest period occurs from December to March.
Among the main volatile compounds identified in Oiti leaves are ursolic acid (3b-hydroxyurs-12-en-28-oic acid), palmitic acid, b-sitosterol and stigmast-5, 22-dien-3b-ol (stigmasterol). ${ }^{14}$ Regarding the composition of Oiti fruits, other studies were identified its main volatile compounds as hexanal, hexanol, 3-hexanone-2-ol and butyl butyrate. $^{15}$ Oiti seeds have been shown to contain kaempferol, kaempferol glycoside, quercetin, rutin, ellagic acid, epicatechin, catechin, chlorogenic acid and gallic acid. ${ }^{16}$

In further studies Oiti leaf extracts have been shown to display antioxidant, ${ }^{17}$ anticholinesterase antibacterial activity ${ }^{18}$ and antiviral effects. ${ }^{19}$ Seed extracts also exhibit antiviral activity. ${ }^{20}$

Several studies were focused on plants from the Chrysobalanaceae family due to their biological activities. For example, the seed extracts of Parinari curatellifolia have been shown to display hepatoprotection against acetaminophen-induced damage, reduce lipid peroxidation in liver tissue, and restore the activities of antioxidant enzyme systems to normal levels. ${ }^{21}$ Licania licaniaeflora exhibits anti-inflammatory and antioxidant activities. ${ }^{22}$ Furthermore, Licania rigida Benth - also known as Oiticica - is used against diabetes in folk medicine. ${ }^{19}$ The main secondary metabolites of this plant family are usually triterpenes, diterpenes, steroids and polyphenols like flavonoids and chromones. ${ }^{10}$ 
The present study aims to characterise the macro-composition of Oiti fruits (lipid, moisture, fibre, sugar and protein), as well as micronutrients and minerals $(\mathrm{Ca}, \mathrm{Cu}, \mathrm{Fe}, \mathrm{P}, \mathrm{Mg} \mathrm{Mn}, \mathrm{K}, \mathrm{Na}$ and $\mathrm{Zn}$ ). In addition, total phenolic and flavonoid content of oiti peel and pulp extracts are evaluated and in vitro antioxidant activities are assessed using metal ion methods to provide free radicals. Finally, the phenolic profile of oiti fruits is assessed for the first time.

\section{Materials and methods}

\section{Raw material}

Oiti fruit samples were collected from Natal, Rio Grande do Norte, Brazil (04'38' S 37030' W) in February 2011 and 2012. In total 245 fruits were collected from 5 different plants. Samples collected in 2011 (190 fruits) were used for physical and chemical analysis and samples collected in 2012 (55 fruits) were used for phytochemical characterization (total phenolic content, total flavonoid content, antioxidant assays and phenolic profile analysis). The plant species was identified by $\operatorname{Prof}^{\mathrm{a}} \mathrm{Dr}^{\mathrm{a}}$ Maria Iracema Bezerra Loiola in the Department of Botany Ecology and Zoology of UFRN.

\section{Fruits collection and sample preparation}

The fruits were separated according to the type of analysis, but all were divided into peel, pulp and seed. 165 fruits were dried in an oven at $105^{\circ} \mathrm{C}$ with forced ventilation, 25 fruits were random chosen and analysed in nature, 55 fruits were dried at $40^{\circ} \mathrm{C}$. The samples dried at $105^{\circ} \mathrm{C}$ were used to determine moisture, proteins, lipids, total fibre, ash and mineral content. Samples dried at $40^{\circ} \mathrm{C}$ were used for highperformance liquid chromatography (HPLC) analysis, total phenolic analysis, flavonoid quantification and antioxidant assays. Samples in nature were used to sucrose and reducing sugars quantification and physical characterization.

\section{Physical characterization}

Individual measurements of mass, transverse and longitudinal diameters were carried out on 190 fruits using a $300 \mathrm{~mm}$ universal caliper (Kingtools). The fruit and seed weights ( $\mathrm{FW}$ and SW, respectively) were obtained by direct individual weighing on an analytical balance (Tecnal MARK Model 210A), while pulp weight (PW) was obtained from the difference between each FW and SW. The pulp percentage was calculated using the formula:

pulp $\%=(P W / F W) \times 100$

\section{Chemical characterization}

The determination of moisture, ash and lipid content follow the recommendations of the Instituto Adolfo Lutz (IAL).${ }^{23}$ Protein content was quantified using the Kjedahl method (AOAC, $\mathrm{n}^{\circ}$ 950.48). Sugar content was measured using the 3,5-Dinitrosalicylic acid (DNS) method. ${ }^{24}$ Fibre content was measured using the Soxhlet method (AOAC n ${ }^{\circ}$ 945.16).

The mineral content was measured by optical emission spectrometry with inductively coupled argon plasma (ICP/OES) method 6010c, United States Environmental Protection Agency (USEPA). The content of total reducing sugars was measured in pulp only, using the DNS method ${ }^{25}$ and the analytical curve of fructose-glucose in interval concentrations of $0.25-1 \mathrm{mg} \mathrm{mL}^{-1}$.

\section{Total flavonoid content}

The total flavonoid content for oiti fruit peel and pulp was quantified using the method described by Marinova et al. (2005). First, $1 \mathrm{~mL}$ of $\mathrm{AlCl}_{3}$ ethanolic solution $\left(20 \mathrm{mg} \mathrm{mL}^{-1}\right)$ was added to $1 \mathrm{~mL}$ hydroethanolic extract $\left(20 \mathrm{mg} \mathrm{mL}^{-1}\right)$. The final volume was completed to $25 \mathrm{~mL}$ and vortexed for 10 seconds, before the mixture was incubated for $40 \mathrm{~min}$ at $26^{\circ} \mathrm{C}$, and the solution absorbance was measured at $429 \mathrm{~nm}$ (Shimadzu UV-Visible mod. 1650 PC, Kyoto, Japan). Finally, the concentrations were quantified using the standard curve of quercetin (Sigma-Aldrich, USA). Samples were analysed in triplicate and data was expressed in mg equivalent of quercetin per $\mathrm{g}$ of sample. ${ }^{26}$

\section{Total phenolic content}

The total phenolic content was evaluated by the Folin-Ciocalteu method. ${ }^{27}$ To an aliquot of each extract $\left(20 \mathrm{mg} \mathrm{mL}^{-1}\right) 2.5 \mathrm{~mL}$ of Folin-Ciocalteu reagent was added $(1: 10, \mathrm{v} / \mathrm{v})$ before vortexing and incubating for $2 \mathrm{~min}$ at room temperature. Subsequently, $2 \mathrm{~mL}$ of $\mathrm{Na}_{2} \mathrm{CO}_{3} 7.5 \%$ was added to the mixture, which was then incubated for $15 \mathrm{~min}$ at $50{ }^{\circ} \mathrm{C}$. Solution absorbance was measured at $760 \mathrm{~nm}$ (Shimadzu UV-Visible mod. 1650 PC, Kyoto, Japan). Quantification was performed by using the gallic acid standard curve $(1.67-10 \mathrm{mg}$ $\left.\mathrm{L}^{-1}\right)$. Samples were analysed in triplicate and data was expressed in $\mathrm{mg}$ equivalent of gallic acid per $\mathrm{g}$ of sample.

\section{Reducing power}

Aliquots of hydroethanolic extracts were diluted with phosphate buffer (200 mM pH 6.6) in glass tubes to a final volume of $1,200 \mu \mathrm{L}$. Next, $200 \mu \mathrm{L}$ of potassium ferricyanide solution $1 \%$ was added to each tube, vortexed, and incubated at $50{ }^{\circ} \mathrm{C}$ for $20 \mathrm{~min}$. Following incubation, $360 \mu \mathrm{L}$ of trichloroacetic acid $10 \%$ was added. Then, to promote potassium ferricyanide reduction $40 \mu \mathrm{L}$ of $0.1 \%$ iron chloride solution was added to all tubes. Finally, $3.0 \mathrm{~mL}$ of $200 \mathrm{mM}$ phosphate buffer $\mathrm{pH} 6.6$ was added, the tubes were vortexed and absorbances were measured at $700 \mathrm{~nm}$ (Shimadzu UV-visible mod. 1650 PC, Kyoto, Japan). Results were expressed as a percentage of the absorbance of $100 \mu \mathrm{g} / \mathrm{mL}$ ascorbic acid solution ${ }^{17}$

\section{Antioxidant capacity}

Pulp and peel hydroethanolic extracts $\left(20 \mathrm{mg} \mathrm{mL}^{-1}\right)$ were added to tubes and the volume was completed to $500 \mu \mathrm{L}$. Subsequently, $500 \mu \mathrm{L}$ of ammonium molybdate solution $\left(40 \mathrm{mmol} \mathrm{L}^{-1} \backslash \mathrm{H}_{2} \mathrm{SO}_{4} 6 \mathrm{~mol} \mathrm{~L}^{-1}\right)$ was added to each tube, followed by $500 \mu \mathrm{L}$ phosphate buffer $(200 \mathrm{mM}$ $\mathrm{pH}$ 6.6) and $5 \mathrm{~mL}$ of deionized water. The mixture was then incubated at $100{ }^{\circ} \mathrm{C}$ for $90 \mathrm{~min}$. The tubes were cooled to room temperature and absorbance was measured at $695 \mathrm{~nm}$ (Shimadzu UV-Visible mod. 1650 PC, Kyoto, Japan). ${ }^{17}$

\section{Extract preparation for HPLC analysis}

Dried oiti peel and pulp were first cleaned with hexane to remove the lipids present in the samples. Phenolic compounds were then extracted with ethanol $70 \%(1: 10, \mathrm{~m} / \mathrm{v})$, dried and resuspended with methanol to the concentration of $5 \mathrm{mg}$ of extract per $\mathrm{mL}$ of solution.

\section{HPLC-DAD analysis}

HPLC analysis was performed in a Varian liquid chromatograph, high efficiency model LC 220, VARIAN detector UV/DAD, autosampler with temperature control, quadripor bomb, using a Phenomenex C18 column (Phenomenex, $4.6 \times 100 \mathrm{~mm}, 2.6 \mu \mathrm{m}$ ) at room temperature (at $26{ }^{\circ} \mathrm{C}$ ), a flow rate of $1.3 \mathrm{~mL} / \mathrm{min}$, isocratic mode, and elution solvents A (formic acid $0.1 \%$ ) and B (Acetonitrile). Absorbance was monitored at $280 \mathrm{~nm}$ and data was analysed with Galaxie software. 
Phenolic compounds were quantified using standard curves ( 0.453 to $100 \mu \mathrm{g} / \mathrm{mL}$ ) for catechin, rutin, kaempferol and gallic acid (SigmaAldrich, USA) ${ }^{28}$

\section{Statistical analysis}

Data was expressed in the form of mean and standard deviations. Pearson correlations were performed using BioStat 5.0.

\section{Results and discussion}

\section{Physical-chemical characterization}

Physical parameters assessed for oiti fruits are described in Table 1. Following the results, the analysed oiti fruits were $36.14 \pm 7.86 \mathrm{~g}$ in weight, with $65.82 \%$ corresponding to pulp, and transversal $(3.21 \pm$ $0.36 \mathrm{~cm})$ and longitudinal $(5.30 \pm 0.60 \mathrm{~cm})$ diameter values forming its oval shape (Figure 1).

Table I Physical characterization of Oiti fruits (Licania tomentosa Benth).

\begin{tabular}{lccc}
\hline \multirow{2}{*}{ Physical Parameters } & \multirow{2}{*}{ Oiti Fruits } & \multicolumn{2}{c}{ Amplitude } \\
& & Minimum & Maximum \\
\hline Transversal Diameter $(\mathrm{cm})$ & $3.21 \pm 0.36$ & 2.40 & 4.80 \\
Longitudinal Diameter $(\mathrm{cm})$ & $5.30 \pm 0.60$ & 4.10 & 7.20 \\
Mass (g) & & & \\
$\quad$ Fruit & $36.14 \pm 7.86$ & 18.58 & 53.75 \\
$\quad$ Pulp & $24.10 \pm 8.68$ & 7.09 & 43.11 \\
$\quad$ Seed & $11.92 \pm 4.71$ & 4.35 & 34.92 \\
Pulp \% & $65.82 \pm 13.10$ & 27.62 & 88.84
\end{tabular}

Data expressed as mean \pm standard deviation; $n=190$, Samples collected in February 20II.

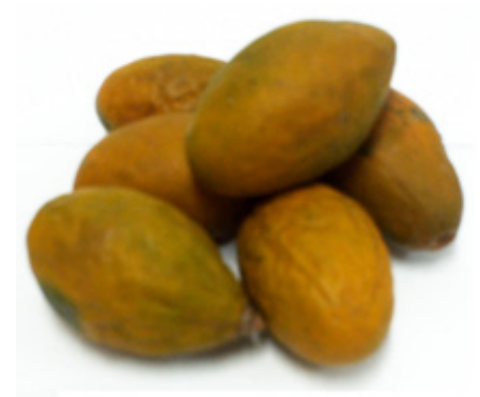

Figure I Oiti fruits (Licania tomentosa Benth).

Oiti fruits showed 34.76, 25.62 and $52.39 \%$ of total carbohydrates (non-reducing sugar, reducing sugar, fibers among other compounds) for pulp, peel and seed samples respectively. Furthermore, Oiti fruit pulp had a total sugar content of $21.53 \%$ (reducing and nonreducing sugars) and $78.57 \%$ of sugar content were reducing sugars such as fructose and glucose (Table 2). Considering carbohydrate quantification by difference $(100 \%$ less all other macro components that not carbohydrates), the main carbohydrate source in peel were fibers ( $85.1 \%$ of total carbohydrates), in pulp were non-reducing and reducing sugars (59.5\% of of total carbohydrates), and while in the seed only $35.1 \%$ of total carbohydrates were fibers. It's importantly to mention that Oiti fruits composition is likely also composed of other structures such as pectin and starch. Oiti fruits had a moisture content of $60.5,72.3$ and $44.4 \mathrm{~g}$ for peel, pulp and seed, respectively, the pulp being the part of the Oiti fruit richest in water. However, peel was found to be the richest part in lipids ( $3.73 \mathrm{~g} / 100 \mathrm{~g}$ of fruit), and the seed in proteins $(2,039 \mathrm{mg} / 100 \mathrm{~g}$ of fruit).
Table 2 Macro and micronutrients content of Oiti fruits (Licania tomentosa Benth).

\begin{tabular}{|c|c|c|c|}
\hline Macronutrients & Peel & Pulp & Seed \\
\hline Moisture (\%) & $60.5 \pm 150$ & $72.3 \pm 0.9$ & $44.4 \pm 1.10$ \\
\hline Ash (\%) & $0.22 \pm 0.00$ & $\mathrm{I} .4 \mathrm{I} \pm 0.0 \mathrm{I}$ & $1.18 \pm 0.01$ \\
\hline Lipids (g/ I00g) & $3.73 \pm 0.09$ & $0.40 \pm 0.04$ & $0.05 \pm 0.00$ \\
\hline Protein (mg/l00 g) & $793 \pm 1.00$ & $258 \pm 2.00$ & $2039 \pm 49.00$ \\
\hline $\begin{array}{l}\text { Reducing Sugars } \\
\quad(\mathrm{mg} / 100 \mathrm{~g})^{\prime}\end{array}$ & NA & $16.26 \pm 0.23$ & NA \\
\hline $\begin{array}{l}\text { Non-reducing and } \\
\text { Reducing Sugars } \\
(\mathrm{mg} / 100 \mathrm{~g})^{\prime}\end{array}$ & NA & $20.70 \pm 0.24$ & NA \\
\hline Fibers (g/l00 g) & $21.8 \pm 0.20$ & $5.67 \pm 0.16$ & $18.4 \pm 0.90$ \\
\hline $\begin{array}{c}\text { Total } \\
\text { Carbohydrates }^{2}\end{array}$ & $25.62 \pm 0.02$ & $34.76 \pm 0.12$ & $52.39 \pm 0.14$ \\
\hline $\begin{array}{l}\text { Micronutrients } \\
\text { (mg/l00g) }\end{array}$ & Peel & Pulp & Seed \\
\hline Calcium & $92.60 \pm 2.07$ & $46.22 \pm 1.92$ & $115.6 \mid \pm 2.18$ \\
\hline Copper & $0.20 \pm 0.00$ & $0.28 \pm 0.01$ & $0.32 \pm 0.00$ \\
\hline Iron & $1.66 \pm 0.02$ & $0.90 \pm 0.03$ & $0.55 \pm 0.01$ \\
\hline Phosphorus & $447.80 \pm 1.30$ & $293.70 \pm 2.30$ & $425.00 \pm 4.50$ \\
\hline Magnesium & $23.44 \pm 0.38$ & $27.88 \pm 0.48$ & $110.70 \pm 0.40$ \\
\hline Manganese & $0.19 \pm 0.01$ & $0.11 \pm 0.00$ & $0.52 \pm 0.02$ \\
\hline Potassium & $627.60 \pm 4.20$ & $848.00 \pm 8.80$ & $584.80 \pm 9.10$ \\
\hline Sodium & $27.02 \pm 0.35$ & $38.96 \pm 0.33$ & $27.02 \pm 0.35$ \\
\hline Zinc & $0.38 \pm 0.00$ & $0.36 \pm 0.00$ & $0.43 \pm 0.02$ \\
\hline
\end{tabular}

Data expressed as mean \pm standard deviation; minerals determined by ICP/ OES, samples analysed in triplicate. I: Non-reducing sugar measured by DNS method; 2: Reducing sugar (glucose and fructose) measured by DNS method; 3: total carbohydrates $=100-$ (Protein, moisture, ashes and lipids content).

\section{Mineral content}

Table 2 presents the results of the calcium, copper, iron, phosphorus, magnesium, manganese, potassium, sodium and zinc content measured from the peel, pulp and seed of Oiti fruits. The peel and seed had the highest calcium content $(92.60 \pm 2.07$ and $115.61 \pm 2.18$ $\mathrm{mg} / 100 \mathrm{~g}$ of fruit) and phosphorus content (447.80 \pm 1.30 and 425.00 $\pm 4.50 \mathrm{mg} / 100 \mathrm{~g}$ of fruit). The seed showed the highest contents of magnesium $(110.70 \pm 0.40 \mathrm{mg} / 100 \mathrm{~g}$ of fruit) and manganese $(0.52 \pm$ $0.02 \mathrm{mg} / 100 \mathrm{~g}$ of fruit).

Considering the Reference Daily Intake (RDI) provided by the Food and Drug Administration (FDA), an intake of $100 \mathrm{~g}$ peel, pulp or seed would contribute to $29.78,20.88$ and $26.00 \%$ of calcium RDI, $13.33,18.67$ and $21.33 \%$ of copper RDI, $55.98,53.13$ and $36.71 \%$ of phosphorous RDI, 11.86, 6.43 and $3.93 \%$ of iron RDI, 31.38 , 42.40 and $29.24 \%$ of potassium RDI, and $9.50,5.50$ and $26.00 \%$ of manganese RDI, respectively. Other minerals would provide a lower contribution.

\section{Total phenolic content, total flavonoid content and antioxidant assays}

Peel showed the highest values of phenolic compounds and flavonoids (Table 3) compared to pulp; this was expected due to its defence function in fruit physiology. ${ }^{29,30}$ However, the total flavonoid/ total phenolic content ratio indicates that flavonoids represent 55\% and $41 \%$ of total phenolic compounds in peel and pulp, respectively. Besides flavonoids other compounds also known as polyphenols 
or phenolic compounds, such as proanthocyanidins, ellagitannins, saponins and terpenes, compounds previously described by other studies on its seed ${ }^{16}$. Oiti peel also showed high antioxidant capacity $(142.24 \pm 0.88 \mathrm{mg} / \mathrm{g}$ of extract) and reducing power (101.14\%); however, a weak correlation was observed between total phenolic content and antioxidant capacity $\left(\mathrm{R}^{2}=0.15\right)$ and reducing power $\left(\mathrm{R}^{2}=0.27\right)$. Meanwhile, pulp showed a weak correlation to total phenolic content and antioxidant capacity $\left(\mathrm{R}^{2}=0.37\right)$ and a moderatestrong correlation to reducing power $\left(\mathrm{R}^{2}=0.83\right)$. These results could be due to different mechanisms of free radical scavenging. However, it should be remembered that other phenolic compounds besides flavonoids are part of the fruit composition, and they may also play a role in the antioxidant capacity and reducing power of Oiti peel and pulp extracts.

Another fruit from the Chrysobalanaceae family is the Guajuru (Chrysobalanus icaco L.), which is also rich in polyphenols exhibited antioxidant activity. ${ }^{31}$ It also shows antidiabetic effects in rats, ${ }^{32}$ as well as antiproliferative and anti-inflammatory activities, ${ }^{8}$ demonstrating the potential of fruits from this family as a source of bioactive compounds, which includes Oiti fruits.

Table 3 Total phenolic, total flavonoids content and antioxidant analysis of hydroethanolic extract of peel and pulp Oiti fruits (Licania tomentosa Benth).

\begin{tabular}{|c|c|c|c|c|}
\hline \multirow{2}{*}{ Parameters } & \multicolumn{2}{|l|}{ Peel } & \multicolumn{2}{|l|}{ Pulp } \\
\hline & $(\mathrm{mg} / \mathrm{g})^{\mathrm{a}}$ & $(\mathrm{mg} / \mathrm{g})^{\mathrm{b}}$ & $(\mathrm{mg} / \mathrm{g})^{\mathrm{a}}$ & $(\mathrm{mg} / \mathrm{g})^{\mathrm{b}}$ \\
\hline Total Phenolic & $\begin{array}{l}1.03 \pm \\
0.01\end{array}$ & $0.30 \pm 0.00$ & $\begin{array}{l}0.59 \pm \\
0.02\end{array}$ & $\begin{array}{l}0.14 \pm \\
0.01\end{array}$ \\
\hline Total Flavonoids & $\begin{array}{l}0.57 \pm \\
0.05\end{array}$ & $0.17 \pm 0.02$ & $\begin{array}{l}0.24 \pm \\
0.00\end{array}$ & $\begin{array}{l}0.06 \pm \\
0.00\end{array}$ \\
\hline $\mathrm{TF} / \mathrm{TP}$ & 0.55 & 0.56 & 0.41 & 0.43 \\
\hline Antioxidant & $142.24 \pm$ & $41.20 \pm$ & $101.14 \pm$ & $22.06 \pm$ \\
\hline Capacity & 0.88 & 0.31 & 9.62 & 1.80 \\
\hline $\begin{array}{l}\text { Reducing } \\
\text { Power (\%) }\end{array}$ & $\begin{array}{l}8.29 \pm \\
0.17\end{array}$ & $2.40 \pm 0.05$ & $\begin{array}{l}4.04 \pm \\
0.05\end{array}$ & $\begin{array}{l}0.94 \pm \\
0.01\end{array}$ \\
\hline
\end{tabular}

a: $\mathrm{mg} / \mathrm{g}$ of extract; $\mathrm{b}: \mathrm{mg} / \mathrm{g}$ of sample;TP:Total phenolic content;TF: Total flavonoids content; Data expressed in $\mathrm{mg}$ equivalent of gallic $\mathrm{acid} / \mathrm{g}$ of extract or $\mathrm{g}$ of fresh sample, mean \pm standard deviation, samples analysed in triplicate.

\section{Phenolic profile}

The Oiti peel (Figure 2A) showed the richest polyphenol profile in comparison to Oiti pulp (Figure 2B). In peel, 4 peaks were tentatively identified by their retention time and absorbance spectrum as gallic acid (peak 1), catechin (peak 2), rutin (peak 3) and kaempferol (peak 6), while two compounds were identified as unknown 1 (peak 4) and unknown 2 (peak 5) (Figure 2A). However, their absorbance spectrum indicates that they could be flavonols (flavonoid class) (Figure 2C).

In pulp it was possible to identify only gallic acid, kaempferol and unknown 2. Considering the flavonoid classes found in peel and pulp, $88.69 \%$ were flavonols and $11.31 \%$ flavanols (catechin) in peel, while $94.25 \%$ of compounds found in pulp were flavonols (Table 4). In other studies, these classes of flavonoids were also found in Oiti seeds. ${ }^{16}$ To the best of our knowledge no previous work conducts polyphenol characterization of Oiti fruit (peel and pulp).
The present data corroborate observations from other species in the Chrysobalanaceae family, such as Licania licaniaeflora, Licania pittieri and Licania pyrifolia, in which the main flavonoids were myricetin, quercetin and kaempferol, all classified as flavonols. ${ }^{33}$
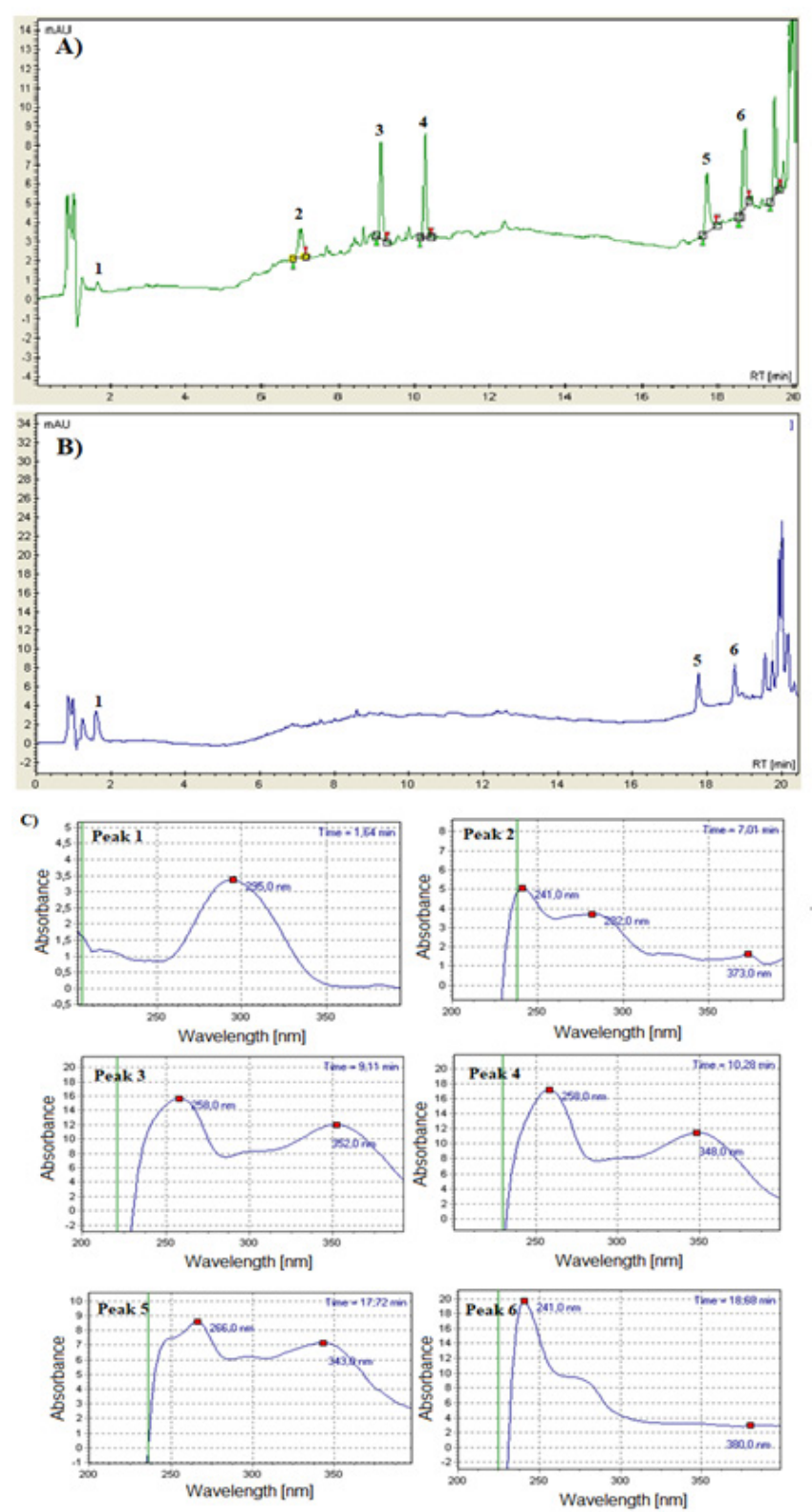

Figure 2 HPLC chromatograms from peel (A) and pulp (B) of Oiti fruits at $335 \mathrm{~nm}$ and the absorbance spectrum for each marked peak $(C)$ : Peak I: Gallic acid, Peak 2: Catechin, Peak 3: Rutin, Peak 4: Unknown I, Peak 5: Unknown2, Peak 6: Kaempferol.

Flavonols are flavonoids that have 3-hydroxyflavone as the backbone structure. This subclass of flavonoid includes isorhamnetin, fisetin, morin and galangin, in addition to the above-mentioned quercetin, myricetin and kaempferol. ${ }^{34}$ The structural difference between quercetin and kaempferol is an additional phenolic hydroxyl group $(-\mathrm{OH})$ in the 3 ' position of the quercetin structure. ${ }^{35}$ The compound identified as rutin is also known as quercetin 3-O-rutinoside, a glycosylated form of quercetin. Other studies have demonstrated that flavonol holds great potential to prevent chronic disease such as cancer, ${ }^{36}$ diabetes $^{37}$ and cardiovascular diseases. ${ }^{38}$ 
Table 4 Quantification of phenolic compounds in Oiti fruits (Licania tomentosa Benth) by HPLC-DAD.

\begin{tabular}{|c|c|c|c|c|c|c|}
\hline Compound & RT & Peel(mg/g) & $\%$ & Pulp(mg/g) & $\%$ & $\lambda(\mathrm{nm})$ \\
\hline Galic Acid* & 1.62 & $\mathrm{Tr}$ & - & $0.15 \pm 0.04$ & 5.71 & 295 \\
\hline Catechin* & 6.99 & $0.59 \pm 0.07$ & 11.31 & ND & - & $24 I / 282 / 373$ \\
\hline Rutin* & 9.11 & $0.82 \pm 0.11$ & 15.84 & ND & - & $258 / 352$ \\
\hline Unknown I & 16.85 & $1.37 \pm 0.02$ & 26.41 & ND & - & $258 / 348$ \\
\hline Unknown2 & 17.52 & $1.15 \pm 0.09$ & 22.25 & $1.20 \pm 0.04$ & 47.02 & $266 / 343$ \\
\hline Kaempferol* & 18.68 & $1.26 \pm 0.10$ & 24.19 & $1.20 \pm 0.01$ & 47.23 & $241 / 380$ \\
\hline \multicolumn{2}{|c|}{ Total } & 5.19 & 100 & 2.55 & 100 & \\
\hline
\end{tabular}

*Identified by retention time and absorbance spectrum. \% considered only the quantified compounds. Unknownl and Unknown2 were quantified as quercetin due to them absorbance spectrum indicated they are flavonols. RT: retention time; duplicated of extraction.

\section{Conclusion}

In conclusion, the collected fruits have uniform length, diameter and a great variation in weight. Given the carbohydrate and lipid contents observed for Oiti fruit, they can be considered a good source of nutrients, such as carbohydrates and lipids, and flavonoids, especially flavonols as myricetin, quercetin and kaempferol. Thus, the Oiti fruit could be used by the food industry as a source of nutrients and antioxidant compounds.

\section{Acknowledgements}

The authors thank the NUPPRAR/UFRN for the mineral analyses. We also would like to thank Profa. Dra ${ }^{\mathrm{a}}$. Cristiane Fernandes de Assis and Prof. Dr. Djalma Ribeiro da Silva for allowing the utilization of equipment in their laboratories and $\operatorname{Prof}^{\mathrm{a}} \mathrm{Dr}^{\mathrm{a}}$ Maria Iracema Bezerra Loiola for identified the plant species. This study was financed by the Coordenação de Perfeiçoamento de Pessoal de Nível Superior Brasil (CAPES) - Finance Code 001, and by Conselho Nacional de Desenvolvimento Científico e Tecnológico (CNPq).

\section{Conflict of Interest}

The authors declare that they have no conflict of interest.

\section{References}

1. Agra M de F, Silva KN, Basílio IJLD, Freitas PF de, Barbosa-Filho JM, Universidade. Survey of medicinal plants used in the region Northeast of Brazil Revisão. 2008;18(March):472-508.

2. Fujita A, Borges K, Correia R, Franco BDG de M, Genovese MI. Impact of spouted bed drying on bioactive compounds, antimicrobial and antioxidant activities of commercial frozen pulp of camu-camu (Myrciaria dubia Mc. Vaugh). Food Res Int. 2013;54(1):495-500

3. Gonçalves AEDSS, Lellis-Santos C, Curi R, Lajolo FM, Genovese MI. Frozen pulp extracts of camu-camu (Myrciaria dubia McVaugh) attenuate the hyperlipidemia and lipid peroxidation of Type 1 diabetic rats. Food Res Int. 2014;64:1-8. doi:10.1016/j.foodres.201

4. Barbosa PO, Pala D, Silva CT, et al. Açai (Euterpe oleracea Mart.) pulp dietary intake improves cellular antioxidant enzymes and biomarkers of serum in healthy women. Nutrition. 2016;32(6):674-680. doi:10.1016/j. nut.2015.12.030.

5. Oyama LM, Silva FP, Carnier J, et al. Juçara pulp supplementation improves glucose tolerance in mice. Diabetol Metab Syndr. 2016;8(1):8. doi:10.1186/s13098-015-0122-4.

6. Teixeira L de L, Costa GR, Dörr FA, et al. Potential antiproliferative activity of polyphenol metabolites against human breast cancer cells and their urine excretion pattern in healthy subjects following acute intake of a polyphenol-rich juice of grumixam
7. Pereira MC, Steffens RS, Jablonski A, et al. Characterization and antioxidant potential of Brazilian fruits from the Myrtaceae family. J Agric Food Chem. 2012;60(12):3061-3067. doi:10.1021/jf205263f.

8. Venancio VP, Almeida MR, Antunes LMG. Cocoplum (Chrysobalanus icaco L.) decreases doxorubicin-induced DNA damage and downregulates Gadd45a, Il-1 $\beta$ and Tnf- $\alpha$ in vivo. Food Res Int. 2018;105(December 2017):996-1002. doi:10.1016/j.foodres.2017.12.009.

9. Andrade EHA, Zoghbi MGB, Maia JGS. Constituintes volateis dos frutos de Licania tomentosa. Acta Amaz. 1998;28(1):55-58.

10. Carnevale Neto F, Pilon AC, Da Silva Bolzani V, Castro-Gamboa I. Chrysobalanaceae: Secondary metabolites, ethnopharmacology and pharmacological potential. Phytochem Rev. 2013;12(1):121-146. doi:10.1007/s11101-012-9259-z.

11. Jud NA, Nelson CW, Herrera F. Fruits and wood of Parinari from the early Miocene of Panama and the fossil record of Chrysobalanaceae. Am J Bot. 2016;103(2):277-289. doi:10.3732/ajb.1500425.

12. Zamproni K, Biondi D, Ribeiro T, Carvalho B De, Louveira FA. Diagnóstico Quali-Quantitativo da Arborização Viária de Bonito , Mato Grosso do Sul. 2018:235-244. doi:10.5380/rf.v48.

13. Monteiro KL, Oliveira C de, Silva, Breno Marques da Silva Carvalho DA de. Caracterização morfológica de frutos, de sementes e do desenvolvimento pós-seminal de Licania tomentosa ( Benth .) Fritsch. 2012:90-97.

14. Castilho RO, Kaplan MAC. Chemical Constituints of Licania tomentosa BENTH. (CRHYSOBALANACEAE). 2008;31(1):66-69.

15. Castilho RO, Kaplan MAC. Volatile components of oiti fruit (Licania tomentosa Benth.). Rec Nat Prod. 2010;4(4):238-241.

16. Pessoa IP, Lopes Neto JJ, Silva de Almeida T, et al. Polyphenol Composition, Antioxidant Activity and Cytotoxicity of Seeds from Two Underexploited Wild Licania Species: L. rigida and L. tomentosa. Molecules. 2016;21(12). doi:10.3390/molecules21121755.

17. Macêdo JBM. Capacidade antioxidante in vitro e avaliação da toxicidade aguda in vivo de extratos de folhas de Licania rigida Benth., Licania tomentosa (Benth.) Fritsch e Couepia impressa Prance (Chrysobalanaceae). 2011.

18. Farias DF, Souza TM, Viana MP, et al. Antibacterial, antioxidant, and anticholinesterase activities of plant seed extracts from Brazilian semiarid region. Biomed Res Int. 2013;2013:510736. doi:10.1155/2013/510736.

19. Agra MDF, Freitas PF De, Barbosa-filho JM. Divulgação Synopsis of the plants known as medicinal and poisonous in Northeast of Brazil. 2007; 17(1):114-140

20. Miranda MMFS, Gonçalves JLS, Romanos MT V, et al. Anti-herpes simplex virus effect of a seed extract from the tropical plant Licania tomentosa ( Benth .) Fritsch ( Chrysobalanaceae ). 2002:641-645. 
21. Olaleye MT, Amobonye AE, Komolafe K. Protective effects of Parinari curatellifolia flavonoids against acetaminophen-induced hepatic necrosis in rats. Saudi J Biol Sci. 2014;21(5):486-492. doi:10.1016/j. sjbs.2014.06.005.

22. Braca A, Sortino C, Politi M, Morelli I, Mendez J. Antioxidant activity of flavonoids from Licania licaniaeflora. 2002;79:379-381.

23. Lutz IA. Métodos Físicos-Quimicos Para Análise de Alimentos.; 2008. doi:10.1017/CBO9781107415324.004.

24. Miller GL. Use of Dinitrosalicylic Acid Reagent for Determination of Reducing Sugar. Anal Chem. 1959;31(3):426-428. doi:10.1021/ ac60147a030.

25. McCleary B V., McGeough P. A Comparison of Polysaccharide Substrates and Reducing Sugar Methods for the Measurement of endo1,4- $\beta$-Xylanase. Appl Biochem Biotechnol. 2015;177(5):1152-1163. doi:10.1007/s12010-015-1803-z.

26. Marinova D, Ribarova F, Atanassova M. Total Phenolic and Total Flavonoids in Bulgarian Fruits and Vegetables. 2005:255-260.

27. Zieliński H, Kozłowska H. Antioxidant activity and total phenolics in selected cereal grains and their different morphological fractions. J Agric Food Chem. 2000;48(6):2008-2016. doi:10.1021/jf990619o.

28. Aznar Ò, Checa A, Oliver R, Hernández-Cassou S, Saurina J Determination of polyphenols in wines by liquid chromatography with UV spectrophotometric detection. J Sep Sci. 2011;34(5):527-535. doi:10.1002/jssc.201000816.

29. Andersen OM, Markham KR. Chemistry, Biochemistry and Applications. Vol 45.; 2006. doi:0-8493-2021-6.

30. Crozier A, Jaganath IB, Clifford MN. Dietary phenolics: chemistry, bioavailability and effects on health. Nat Prod Rep. 2009;26(8):10011043. doi:10.1039/b802662a.
31. Gonçalves NP, Lucena EMP de, Bonilla OH, Silveira MRS da. Polyphenols and Antioxidant Activity of Four Fruits Native to the Coast of Ceara Under Different Maturation Stages. Rev Bras Frutic. 2017;39(1):17. doi:10.1590/0100-29452017460.

32. Barbosa APDO, Silveira GDO, de Menezes IAC, et al. Antidiabetic effect of the Chrysobalanus icaco L. aqueous extract in rats. J Med Food. 2013;16(6):538-543. doi:10.1089/jmf.2012.0084.

33. Feitosa EA, Xavier HS, Perrelli K. Chrysobalanaceae: traditional uses, phytochemistry and pharmacology. Brazilian $J$ Pharmacogn. 2012;22(5):1181-1186.

34. Butun B, Topcu G, Ozturk T. Recent advances on 3-hydroxyflavone derivatives: Structures and properties. Mini-Reviews Med Chem. 2018;18(2):98-103. doi:10.2174/1389557517666170425102827.

35. Del Rio D, Rodriguez-Mateos A, Spencer JPE, Tognolini M, Borges G, Crozier A. Dietary (Poly)phenolics in Human Health: Structures, Bioavailability, and Evidence of Protective Effects Against Chronic Diseases. Antioxid Redox Signal. 2013;18(14):1818-1892.

36. Darband SG, Kaviani M, Yousefi B, et al. Quercetin: A functional dietary flavonoid with potential chemo-preventive properties in colorectal cancer. J Cell Physiol. 2018;233(9):6544-6560. doi:10.1002/jcp.26595.

37. Mahmoud MF, Hassan NA, El Bassossy HM, Fahmy A. Quercetin Protects against Diabetes-Induced Exaggerated Vasoconstriction in Rats: Effect on Low Grade Inflammation. PLoS One. 2013;8(5). doi:10.1371/ journal.pone.0063784.

38. Abbas M, Saeed F, Anjum FM, et al. Natural polyphenols: An overview. Int J Food Prop. 2017;20(8):1689-1699. doi:10.1080/10942912.2016.12 20393. 